\title{
UNU-WIDER
}

World Institute for Development

Economics Research

Research Paper No. 2007/02

\section{Housing Privatization and Household Wealth in Transition}

\author{
Ruslan Yemtsov*
}

January 2007

\begin{abstract}
All countries in transition experienced increases in inequality. They have also undertaken massive privatization of key asset housing, often on give-away terms. Are these two phenomena related? Has transfer of ownership rights to residents slowed down the inequality increases or it pushed it up? Surprisingly little is known in this area. This paper attempts to provide empirical evidence to start answering these questions. It shows how housing privatization affected the distribution of personal wealth and inequality in current consumption based on recent representative household surveys from three transition countries: Poland, Russia and Serbia. Survey data are compared with figures derived from national accounts and housing statistics. Contrary to common belief and some earlier evidence of strong equalizing effect of housing distribution in Eastern Europe and the former Soviet Union, the paper finds that the contribution of housing to the overall inequality levels is not strong, and is not universally progressive. There is also a significant variation across countries. In Russia and Serbia .../
\end{abstract}

Keywords: Russia, inequality, wealth distribution, housing, privatization JEL classification: P3, D1, D3, D4

Copyright (C) UNU-WIDER 2007

*The World Bank

This study has been prepared within the UNU-WIDER project on Personal Assets from a Global Perspective, directed by Jim Davies.

UNU-WIDER acknowledges with thanks the financial contributions to its research programme by the governments of Denmark (Royal Ministry of Foreign Affairs), Finland (Ministry for Foreign Affairs), Norway (Royal Ministry of Foreign Affairs), Sweden (Swedish International Development Co-operation Agency_Sida) and the United Kingdom (Department for International Development).

ISSN 1810-2611 ISBN 92-9190-941-6 ISBN 13 978-92-9190-941-4 
progressive. There is also a significant variation across countries. In Russia and Serbia features of privatization programmes resulted in better off households capturing more valuable housing assets on extremely beneficial terms, while in Poland privatization and housing reform led to more equitable outcomes. When owner occupied housing rents and durables are properly accounted for, the effects of housing ownership on inequality in current consumption are mildly progressive in Russia and Poland and regressive in Serbia. The paper argues that the information collected by regular household surveys provides only a starting point to study housing wealth distribution, and there are a number of gaps which should be addressed through improved data collection.

\section{Acknowledgements}

This paper has been revised following presentation at the UNU-WIDER project meeting on Personal Assets from a Global Perspective in Helsinki, 4-6 May 2006. The author is grateful to the meeting participants and Tony Shorrocks for useful comments. Special thanks to the Project Director, Jim Davies, for his review of the first draft, encouragement and suggestions. Views expressed are the author's and do not necessarily represent those of the World Bank.

The World Institute for Development Economics Research (WIDER) was established by the United Nations University (UNU) as its first research and training centre and started work in Helsinki, Finland in 1985. The Institute undertakes applied research and policy analysis on structural changes affecting the developing and transitional economies, provides a forum for the advocacy of policies leading to robust, equitable and environmentally sustainable growth, and promotes capacity strengthening and training in the field of economic and social policy making. Work is carried out by staff researchers and visiting scholars in Helsinki and through networks of collaborating scholars and institutions around the world. www.wider.unu.edu publications@wider.unu.edu

UNU World Institute for Development Economics Research (UNU-WIDER)

Katajanokanlaituri 6 B, 00160 Helsinki, Finland

Typescript prepared by Lorraine Telfer-Taivainen at UNU-WIDER

The views expressed in this publication are those of the author(s). Publication does not imply endorsement by the Institute or the United Nations University, nor by the programme/project sponsors, of any of the views expressed. 


\section{Introduction}

There is a growing recognition of the importance of studying wealth distribution globally, as well as in developing and transition economies (Davies and Shorrocks 2005). Understanding the distribution of wealth is important on its own right as an indicator of social cohesion. The stock of available assets also determines the ability of households to withstand shocks, and inequality in its distribution is linked to intergenerational transmission of poverty. Even in rich countries with diversified portfolios, housing represents the largest part of household wealth. From analysis of the balance sheets of a number of rich countries one can infer that housing accounts for an average of 35 to 45 per cent of total household wealth. In developing countries housing accounts for similarly large share (see Davies and Shorrocks 2005 for a review; Aron et al. 2006 for South Africa; Li and Zhao 2006 for China; Subramanian and Jayaraj 2006 for India).

Distribution of housing is typically determined by institutional factors and changes relatively slowly (see Muellbauer 2006 for a review). Rapid shifts in the distribution of property titles are therefore of particular interest to researchers. Land reforms represent one type for such a change (see Torche and Spilerman 2006). Massive privatization programmes, which all transition economies undertook, form another type and studying their outcomes may help to gain insights about how redistribution policies affect inequality. During 1991-99 as much as 28 per cent of housing stock in transition countries of Eastern Europe and the former Soviet Union (FSU) was privatized. This figure ranged from 7 per cent in Georgia, to over 60 per cent in Estonia and Kazakhstan. Privatization of housing was part of a much broader programme which affected the distribution of productive assets and the functioning of economy as a whole, again with important cross-country differences.

The sheer size of asset value affected by housing privatization appears to be extremely large. An influential report of the World Bank (2001) estimated a total wealth transfer due to housing privatization across all European and Central Asian (ECA) countries to equal as much as US\$1.1 trillion, which is equivalent to roughly US\$3,300 per capita transfer of wealth. 1

\footnotetext{
1 The estimate derived in World Bank (2001) is based on opportunity cost approach. It uses assumptions about how much people are willing to pay for their housing using the relationship between the housing value and their incomes. It takes the conservative estimate of 3.5:1 as the house price to annual income ratio (average privatized dwelling unit price is estimated thus at US\$22,564). Using average family size in these countries of 2.2 the study found family income by multiplying weighted GDP per capita in 1999 by 2.2. Then, using the assumed income to value of housing ratio, they calculated house value per household. To get housing value transferred during privatization, they multiplied the number of households in the region, house value per household and weighted percentage of housing privatized between 1991-99 (28 per cent).
} 
These are large values, but little is known about effects of this process on inequality in housing wealth distribution in transition economies. To illustrate this, it is sufficient to mention that to the best of the author's knowledge not a single transition economy is included in the Luxembourg Wealth Study and no data on Gini index for housing values is available for ECA. Moreover, inequality measurement in transition economies is plagued by little attention to the issue of owner-occupied housing - as a rule no imputed rents are included in the official measurement of income or consumption through representative household surveys, and even when they are there is no consistency of treatment across countries. Even less data is available on how housing wealth inequality compares to other countries and the effects it has on the distribution of incomes (or consumption). We do not know in any systematic way how the indices of income inequality in transition economies will look like when service flow from owneroccupied housing is properly taken into account.

Based on the survey data in three transition countries - Poland, Russia, and Serbia - this paper attempts to provide empirical evidence about the distribution of housing stock as economic asset in transition economies, its relative role compared to other forms of wealth holding, and its effects on the distribution of current consumption. 2 Three countries selected for this paper pursued different types of privatization programmes and were characterized by different initial conditions. The spectacular development of housing and rental markets in transition economies makes such measurement possible and helps to provide plausible and meaningful economic values for asset pricessomething that was totally out of the question in early transition. Survey data are compared with figures derived from national accounts and housing statistics. There are increasing policy demands to better understand housing distribution. Transition economies are engaged in housing policy reform which requires better data. In another part of the transition world China is undertaking profound reforms in the housing sector amidst rapidly raising inequality and policy lessons from housing privatization in ECA may be useful.

The paper is organized into six sections. Section 2 expands the background by reviewing housing privatization programmes in transition economies, and aggregate data on distribution of housing stock by ownership during the transition in the countries of Eastern Europe, and the FSU. Section 3 examines broad measurement issues for housing assets valuation and discusses expected impact of privatization on inequality.

\footnotetext{
2 The paper does not discuss land reforms. Land privatization was an important reform in many transition economies redistributing vital asset in the low-income Commonwealth of Independent States (CIS) countries, with significant variation across countries. As much as 90 per cent of arable land was transferred to households on highly beneficial terms in Albania and Armenia, between one-half and threequarters in Romania, Estonia, Latvia, and Moldova, one third in Kyrgyzstan and Georgia, but only 10-20 per cent in Russia, Kazakhstan, Ukraine and Uzbekistan (Rozelle and Swinnen 2004). Despite initial fears of potential regressive effects (Flemming and Micklewright 1999) restitution of land to former owners was not shown empirically to have a sizeable effect on inequality (Macours and Swinnen 2005).
} 
Section 4 presents survey data used in the study for the three countries in our analysis: Poland, Russia, and Serbia. It discusses in some depth the results of multiple experiments in valuing housing and other household assets in Serbia conducted over 2002-03. Section 5 presents the findings. Section 6 concludes with a discussion putting the new figures on distributional effects of housing privatization in the context of the available literature, points to the policy implications, and identifies gaps to be addressed in future research.

\section{Housing ownership in transition economies}

Transition countries in Eastern Europe and FSU began housing reform by privatizing housing, generally by simple give-away schemes (most frequently by selling housing units at prices well below market valuations). Privatization was accompanied by series of reforms aimed at creating institutions for housing markets and often by encouraging homeownership. The housing sectors as a whole moved closer to a market system with elimination of subsidies for utilities, emergence of private finance and land markets. The result of these combined trends is presented on Figure 1.

Figure 1: privatization outcomes by 1999: share of housing in private hands

\section{$\square 1990 \square$ Housing Wealth Shift}

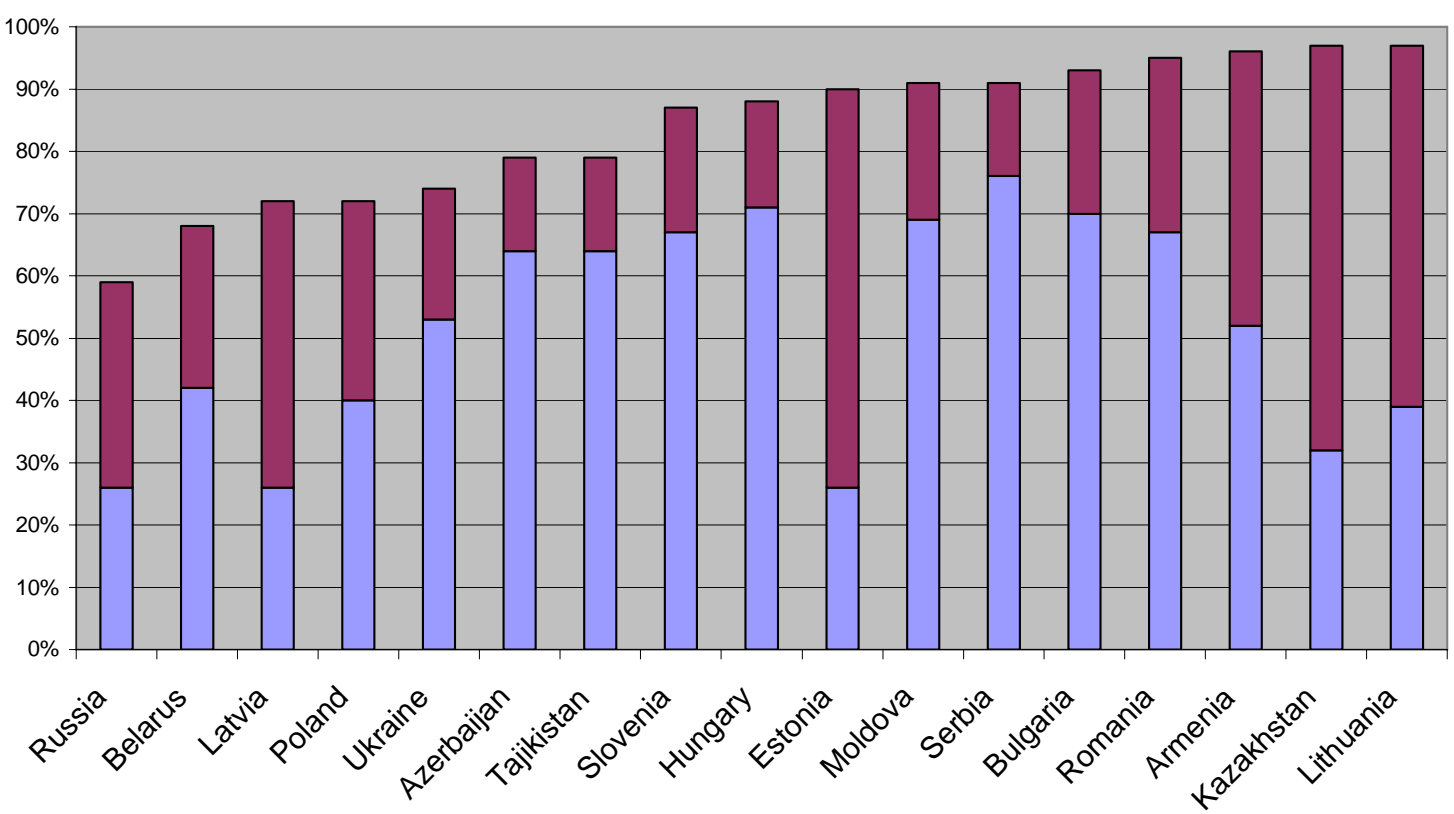

Source: World Bank (2001).

Figure 1 presents data on the change in private ownership for housing assets over 199199 for 17 transition countries. The figure shows the share of housing in private hands (measured by square meters of living space) at the start of transition and by 1999. The scale of ownership transfer is massive in some countries (Estonia, Latvia, Kazakhstan), and is quite impressive everywhere with a median value of one third of housing stock 
moving from public to private homeownership. Although most privatization programmes were essentially give-away schemes, in many countries, notably Russia and Belarus, a substantial portion of the stock continues to remain in public hands. The figure also demonstrates that many countries had a substantial private housing stock in 1990, at the beginning of transition, but for different reasons. In Hungary, Slovenia and Serbia private housing ownership in urban areas was a frequent phenomenon even during the socialist era. In Moldova, Bulgaria, Romania, Tajikistan, and Azerbaijan the relatively large share of housing in private ownership was a reflection of low urbanization rates. Rural areas, even under socialism, largely preserved private ownership on housing (but not on the land on which they were built). But in some countries large agricultural enterprises built multi-story apartment buildings in rural areas hence creating 'urbanized' housing publicly owned structures amidst traditional rural landscape. Unlike in China's transition, rural population therefore was not totally excluded from housing privatization programmes in Eastern Europe and the FSU. In urban areas too, housing was heterogeneous. Some families lived in privately owned single-family houses, which commonly lacked access to basic infrastructure services and were of lower quality. Co-operative housing, which required some self-financing, was inhabited by somewhat higher earners.

Figure 1 suggests that by early 2000 most transition countries had converted to rather high ownership rates (above 80 percent) when compared to 50-60 per cent as typically observed in developed market economies. This is a puzzling outcome-Figure 2 provides evidence why this is the case. The idea behind Figure 2 is that multi-family (MF) structures are more efficiently managed by large private companies which typically rent out individual units to tenants. Thus the higher the share of MF buildings in the housing stock, the larger the share of non-owner tenants than one would expect. Large residential buildings and structures inherited from the past - often representing an encapsulated 'soviet' life style - are still standing in major cities across the region giving a vivid reminder of their common history. Indeed, for market economies this relationship holds true, as Figure 2 suggests (with Spain being an outlier). In transition economies (with exception of the Czech Republic) this relationship shifts significantly with too many owners for the physical characteristics of their stock.

This picture suggests that privatization has not produced yet an efficient market. Scholars studying housing markets point out that often changes in supporting legislation (governing land markets and financial sector) lagged behind ownership reforms, and there were various policy biases against rental market participants. The in-depth review of legislation (UNECE) shows privatization and housing market reforms were not conducted seamlessly or efficiently anywhere. Such distortions are likely to result in inequitable outcomes. 
Figure 2: MF buildings and tenure structure, OECD versus TE

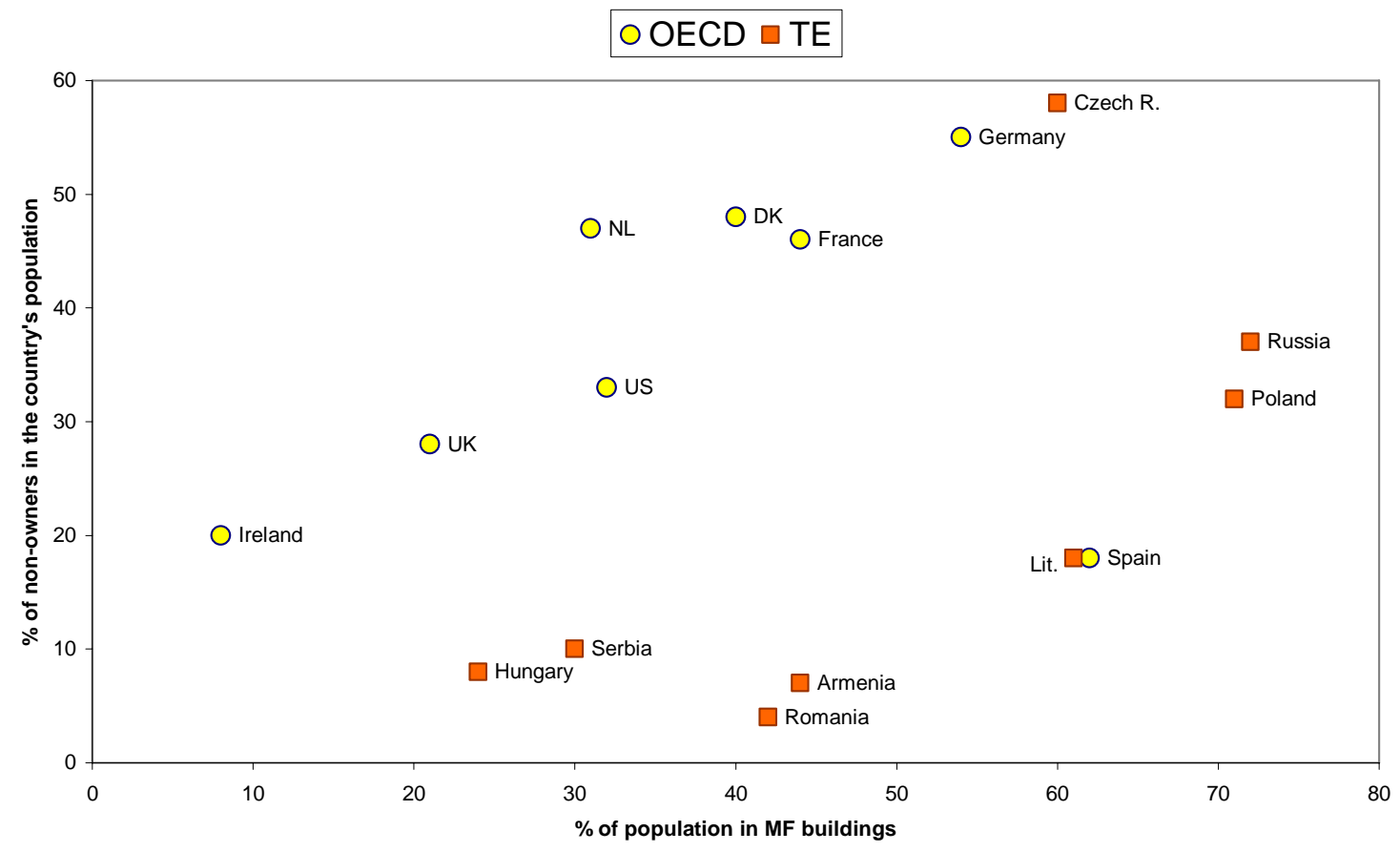

Source: Dübel et al. (2005).

\section{Effects of housing privatization in transition on inequality}

Liberalization of markets led to rapid increases in inequality during the early years of transition, and despite an apparently common legacy and common circumstances of transition, the outcomes appear to show great variations across countries. ${ }^{3}$ Clearly, housing privatization was part of the broad reform packages everywhere and deeply affected their distributional outcomes (Flemming and Micklewright 1999). But how it affected inequality is much less clear-according to one view it was an equalizing factor, according to others it might have led to real or spurious increases in inequality.

\subsection{Stylized facts on housing ownership under socialism: implication for inequality in transition}

Let us start with a simplistic model presenting some stylized facts. Countries in transition have a common legacy of suppressed inequality. This was also true for the housing conditions. Typically a household in a planned economy would reside in a small publicly owned unit (by state or enterprise), pay (subsidized) rent which did not reflected any economic value, and enjoyed protection and security of tenure that would make it similar to extended user rights (Alexeev and Gaddy 1993). As most households had similar housing conditions at the start of market reforms and their tenants rights in

3 Commander et al. (1999). For the most recent review of empirical evidence on inequality in all transition economies of Eastern Europe and FSU; see Mitra and Yemtsov (2006). 
fact gave them a lot of control over their units, privatization by transferring the ownership titles to the tenants had little effect on the distribution of economic wealth as an outcome, but in the process it might have created a spurious hike in inequality. 4

Let us assume that there are only four households in an economy. They occupy identical public housing units worth $\$ 10,000$ (regardless of age). Since they are not part of private assets holdings, initially inequality is zero. Let us assume that the housing privatization in this economy gradually (over four years) gives property rights to the occupants at constant rate of one household per year. At the end of the exercise all housing is in private hands, and since it is all identical inequality will be zero again, but in the process spurious wealth inequality will be generated reaching a maximum in the second year of the programme (Gini of 0.167 ).

Similar dynamics can be inferred for housing as a component of current consumption (and income). Originally, all households have to pay equal amount as rent to the state and if we look at their expenditures the inequality between these identical households is zero. As tenants who decide to privatize no longer have to pay the rent, spurious inequality emerges. This bias may be further worsened by the fact that the state may wish to decide to charge owners higher utility payments compared to those who remain in public housing (privatization for free serves as a screening device to identify those who are able to afford payments reflecting full cost recovery). If imputed rents for the privatized housing will be included into the measure of current consumption, but actual rents will be used for public housing (typical statistical practice), inequality measures will be upward biased. This simple example shows that measuring inequality in wealth and current consumption/income levels requires careful examination. It has to rely on either exclusion of all rents from the measured consumption data 5 as the second best solution, or on comprehensive imputation of rents for proper measurement of income inequality and housing values to reflect user rights in measuring wealth inequality.

Most of the literature on inequality in transition reveals that accounting for distribution of housing has an equalizing effect and housing privatization is equity enhancing. An example of such careful analysis by Milanovic (1990) of the pre-transition situation in a number of economies in East Europe shows overall egalitarian pattern of distribution for housing wealth with no noticeable effects on the inequality levels. 6 Only a handful of studies directly address the issues of equity aspects of housing privatization or distributional effects of housing sector reform for Commonwealth of Independent States

\footnotetext{
4 This is of course an oversimplification, given deviations from the 'standard' in all countries discussed above.

5 An approach followed by World Bank (2005a) and by Mitra and Yemtsov (2006).

6 This needs to be qualified as very approximate given underdeveloped housing markets in these countries and very arbitrary valuations of wealth.
} 
(CIS). Perhaps the most well known example is a study by Buckley and Gurenko (1997). Using RLMS data and estimating imputed rent they report that the inequality in the total consumption was significantly lower in Russia in 1993 than measured by reported expenditures alone: the Gini index falls from an apparent 0.417 to an actual 0.354 when proper accounting is made for imputed rents (but other components were not carefully checked). In a more recent and comprehensive attempt by Tesliuc and Ovcharova (2007), accounting for imputed rents (and utility subsidies) reduces the consumption Gini from 0.29 to 0.26 (data for 2003). This line of reasoning is based on a number of simplifications. Most importantly, studies so far have looked at inequality in current consumption and income and focused on implications of both user and ownership rights. None has looked directly at the distribution of housing assets as opposed to user rights for the publicly owned housing. In reality the effects of housing wealth transfer could have been not as equitable as it seems. Once these factors are listed, serious doubts arise regarding its progressive effects of housing privatization on distribution.

First, the distribution of housing stock has not been as equal and homogeneous under socialism as simplistic reasoning would assume. There was always a chunk of private ownership, reaching as much as 50 per cent in some Central and Eastern European (CEE) countries. Rural residents and dwellers in small cities typically owned their own homes. These groups have not participated in housing privatization and have received nothing from it. But they were the ones who have lost out as a result of economic restructuring in transition (World Bank 2005a).

Second, there was a significant stratification of housing quality under socialism. It is well documented that socialist system favoured elites in providing significantly better housing, free of charge (in that respect the experience of ECA countries was not different from China; see Li and Zhao 2006). They typically have benefited from transition using their social capital, and the housing transfer provided to them dwarfs what the poor have received as a result of marketization of their poorly constructed buildings on city outskirts (see Bertaud and Renaud 1997).

Third, the housing stock transferred through privatization may not be as marketable or may have highly unequal market valuations. Years of central planning resulted in construction without reference to land values producing spatial patterns of housing stock at odds with those that would have been produced in response to market forces. The well known figures based on research by Bertaud and Renaud (1997) made evident the stark contrast between residential density by distance from the city centre in a market-based economy and distorted allocation inherited from the command system. In the former, residential density is greatest near the city centre, where land values are highest, and decreases with distance. In the latter, quite the opposite is true and the construction of large numbers of high-rise apartment buildings on city fringes in successive rings mean the greatest residential density is found on the least valuable land. 
The resulting spatial misallocation of housing creates costs for residents (who need to commute longer distances) and the city (which has to provide city services to remote locations). Additionally, housing quality varied significantly by age of construction. Since a large area in a city was usually developed at one time, this meant that housing quality varied by location. The construction of large amounts of poor quality housing in remote locations provides a concentration of cheap housing stock that is likely to be increasingly filled with the poor as better off residents move to better locations.

Fourth, the housing privatization was also often partial. The apartment units have been privatized, but not the land under the buildings and not common areas and structures; privatization laws often did not clarify ownership of common areas in apartment buildings. Local governments were much more concerned with the ability of households to absorb additional current costs than with maintaining the value of housing stock. As a result multi-story apartment buildings largely have not been maintained (see Struyk 1996). Leaking roofs and internal piping and energy losses from poorly insulated buildings are the most prevalent problems, and buildings are estimated to use two to three times as much heating as buildings in comparable climates in Western Europe (World Bank 2003). All of which suggests that a considerable part of the housing stock in transition countries functions inefficiently in meeting the population's housing needs and its market value is significantly below a common standard.

Contrasting early empirical evidence pointed to rather unequal outcomes of housing privatization which were disequalizing (see Guzanova 1998; and most recently Zavisca 2005). As both views refer to empirical evidence and recognize significant limitations of data at hand, using most recent improved data one can look at the distribution of housing as an asset and its effect on current levels of wellbeing.

\subsection{Outcomes of housing privatization and inequality at the aggregate level}

Different sets of inequality data from transition countries support often conflicting views. A concerted effort has been made to ensure comparability for data in consumption inequality in a recent study by the World Bank (2005b). The data presented below rely on consumption as a most accurate measure of wellbeing 7 and

\footnotetext{
7 The choice of consumption rather than income was dictated by practical considerations. Income data remain particularly difficult to collect in transition countries. In contrast, practice has shown that consumption data can be gathered with a great degree of precision. Spatial Paasche price indices were used all countries and quarterly CPI (IMF) indices were used to compute real values. A consistent approach in assigning a monetary value to in-kind components of consumption was applied. To adjust for differences in household composition we took the simplest approach and used the per capita scale. Finally, the same procedure, which conforms to methods used in other international household survey data depositories such as the Luxemburg Income Study, was used to clean the outlier data. As a consistent approach was followed across all datasets, one can be reasonably confident that differences across countries in the consumption measure are due to differences in the primary data and are not due to the method of aggregation.
} 
exclude all rental costs from consumption aggregate. This helps to avoid biases due to housing ownership and are similar to the 'before housing cost' measurement of expenditures and incomes taken as a benchmark in inequality comparisons across countries (Sierminska and Garner 2002). The broad pattern on homeownership based on this data is evident on Figure 3.

Figure 3: Changes in housing ownership by consumption quintiles over time

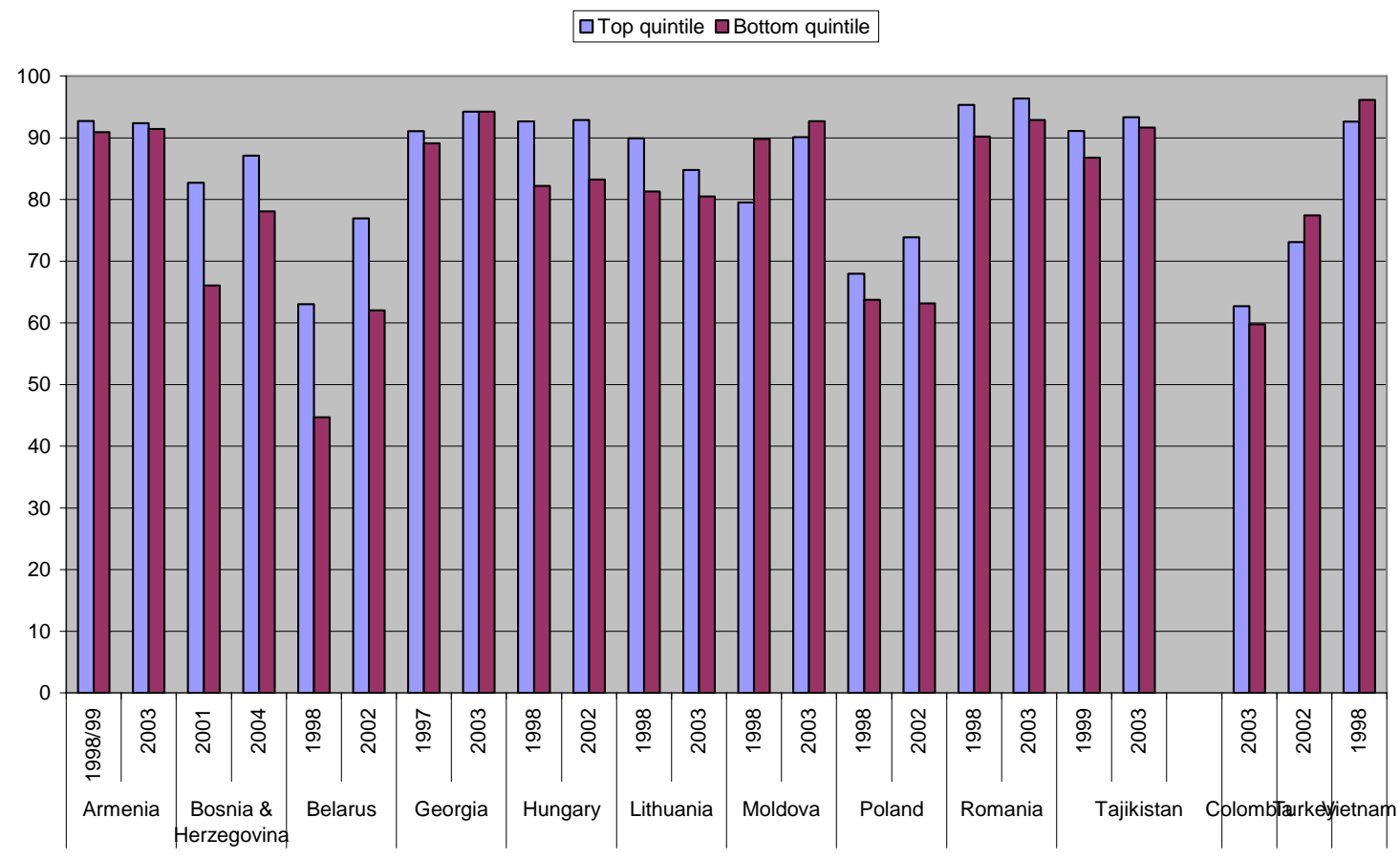

Source: World Bank (2005a).

Figure 3 helps to see that housing ownership in itself does not help to differentiate between rich and the poor, not only in transition economies but also in three 'benchmark' cases used as comparison. This conclusion is supported by data from many countries in Latin America reported in Torche and Spilerman (2006); there, between 60 and 90 per cent of households in the lowest decile own their dwellings and there is sometimes a reverse relationship between ownership and income levels, similar to what is observed in Moldova.

Have these homogeneous ownership rates implied a more egalitarian distribution, especially in countries with large housing privatization programmes? Or was it a factor significant enough to slow down inequality increases driven by other factors? Figure 4 tries to investigate this question by simply confronting the size of ownership transfer between 1990-99 to the change in inequality over the same period. 
Figure 4: Housing wealth shift and change in inequality, 1990-99

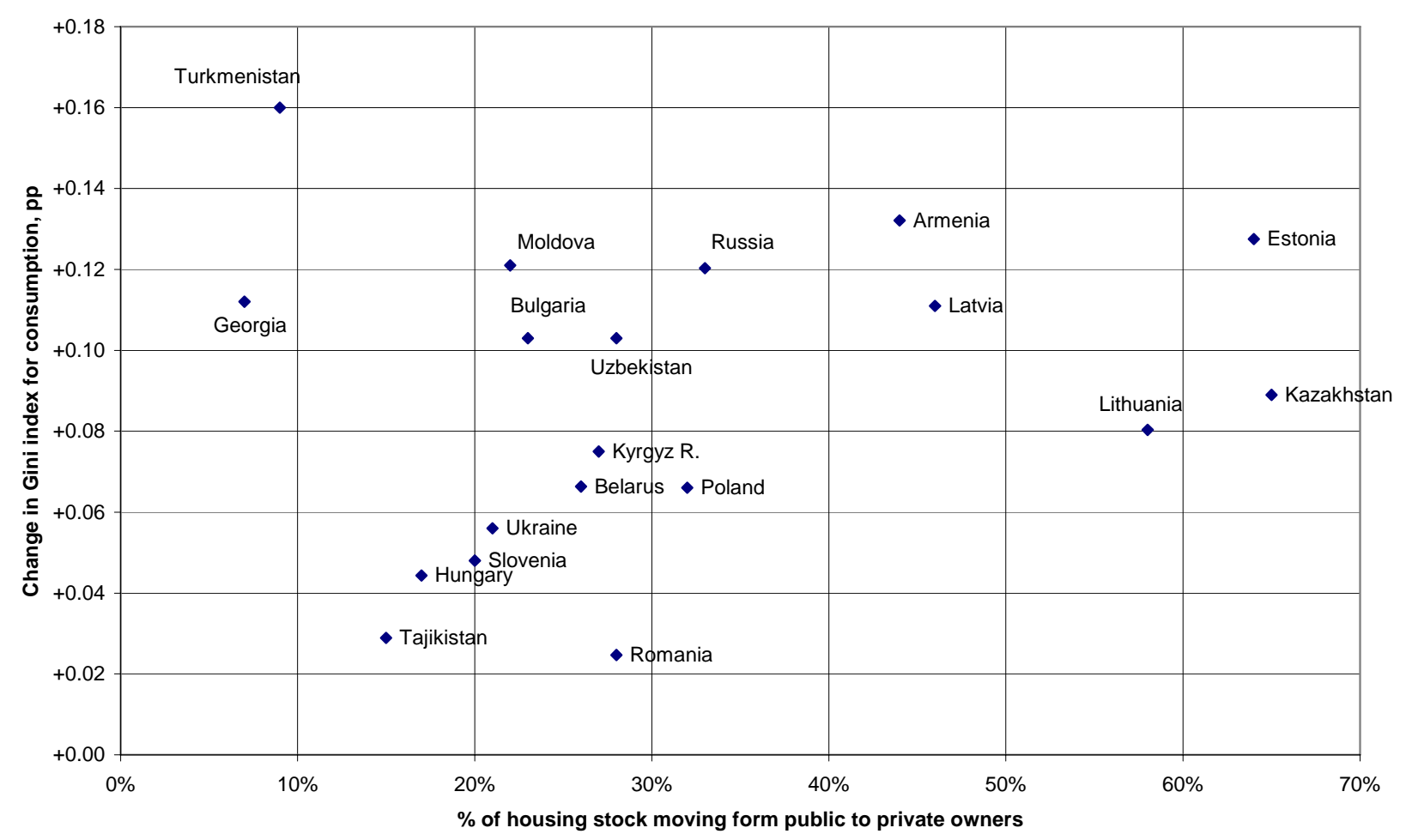

Source: Own estimates based on World Bank (2001) and from Mitra and Yemtsov (2006).

Measures of inequality used here are based on official data and do not fully reflect the work on the comparable 'second best' consumption indicator referred to above. It shows no apparent relationship between the size of privatization programme and changes in inequality in a cross-country perspective. If anything, one may see some signs of positive association (especially if the clear outliers of Turkmenistan and Georgia are removed). Every country with a shift in housing ownership of more than 30 per cent has an increase of over 6 percentage points in the Gini index. That positive link is contrary to common belief according to which privatization counteracts inequality increases. But as we discussed due to biases in the existing readily available welfare measures, this relationship may reflect a spurious correlation between (incorrectly) measured inequality and privatization of housing stock.

Despite this apparent lack of correlation, it is obvious that housing privatization programmes created winners and losers depending on where people happened to be living at the beginning of transition. Those in well located larger units in areas with a sound economic basis received far more valuable assets than did residents of collapsing mono-industrial cities or remote and underserved suburbs. It is noteworthy that since most privatization programmes have not yet closed, households living in social housing who have the right to privatize their units should also be considered winners or losers since they cannot be evicted, can easily privatize and sell, and also often sublet units on the private markets. 


\section{Data and features of housing privatization for Poland, Russia, and Serbia}

Given significant variations of housing privatization programmes across countries it will be particularly interesting to study its effects in a comparative perspective. Recent advances in data availability in transition economies 8 has led to proliferation of studies on household welfare taking advantage of micro datasets from representative household surveys. However, so far none of the countries in the region has special surveys of household assets or debts, which is the case in many OECD countries. 9

The author is not aware of any household expenditure and income survey in the region in which households are asked to report the market value of their housing, let alone financial and other productive assets and debts. Moreover, very often the information collected on household belongings is so abbreviated that it is impossible to do any indirect estimates described below. The choice of countries for the analysis of housing privatization was therefore not very wide. Within a subset of countries with suitable surveys three were selected based on the quality and comprehensiveness of collected data and characteristics of their housing privatization programmes: Poland, Russia, and Serbia.

\subsection{Housing privatization in Poland, Russia, and Serbia}

In each of these three countries privatization programme included give-away schemes for tenants of public housing. The terms of such transfers differed, and even more so, supporting changes in housing policy and legal framework.

Poland started the transtion with a significant share of housing stock in private hands, mostly as ownership of housing co-operatives (Markham 2003). One of the first acts of the new government in 1990 was to devolve ownership of public housing to the newly established local governments, transferring the reponsibility for housing maintenance. In addition state-owned land was made available for private development. There was a one-time title transfer at below market price and was supported by a package of reforms that created a proper framework for the housing sector, including rapid reform of utilities to achieve cost recovery, proper titling of co-operative stock, enabling legislation for private investors, land reform, clear delineation of property rights, and restitution to former owners. Social policy and affordability concerns played a significant role in retaining municipal housing as a sizeable fraction of the housing. The focus being on developing markets and transformation of co-operative ownership into condomuniums (Dübel et al. 2005).

\footnotetext{
8 Discussed in World Bank (2005a), and in Mitra and Yemtsov (2006).

9 See the paper on the Luxembourg Wealth Survey by Jäntti and Sierminska (2006), or even in developing countries - see for instance the paper on India by Subramanian and Jayaraj (2006).
} 
Russia pursued a policy of effectively giving away public- and entreprise-owned housing stock over a long period of time, while continuing large public housing construction. Households were given an option to privatize at a symbolic (book value) price and that option remained open till the adoption of the New Housing Code in 2006. In parallel housing stock owned by enterprises has been divested to the municipalities. The rental controls and utilities price policy were intended to slow down the pace of privatization in effect providing significant subsidies to households opting not to privatize. Tenancy rights remained strong (eviction is still nearly impossible). Rents were kept artificially low and standardized and the amount charged in principle should equal the maintenance fee, but owners are also expected to pay property taxes not paid by renters. Renters remain legally entitled to improved state-provided housing if living in sub-standard (e.g. overcrowded accommodations) and were reluctant to privatize their existing poor quality units, which would render them ineligible for a better unit from the municipality. At the same time the country was developing a legal framework to ensure housing market operations. The main impediment was controversy over the public ownership on land and structures/common areas in MF buildings (Struyk 1996).

Serbia, while historically posessing the largest private housing stock, undertook privatization which was a one-time event rapidly transferring publicly owned units to their tenants for a symbolic price. But there was a missing legal framework, contradictions between different laws governing housing market, and unclear delineation of ownership and user rights for housing and maintenance obligations. Vast parts of the country (rural areas) were practically excluded from any housing reform (UNECE 'Serbia and Montenegro').

\subsection{Surveys}

This paper relies on income and expenditure surveys with sufficient housing data for each country.

Poland: the study is based on household budget surveys (HBSs) conducted by the Central Statistical Office (CSO). Since 1993, the annual HBS sample contains over 31,000 households, or about 100,000 individuals. The Polish HBS provides data on household income, expenditures, type of residence, housing conditions, durables, land area (if any), etc. Fairly detailed information is also given for each household member. The HBS provides information on whether the household has a particular type of durable, and how many items - but does not provide information on their quality (estimated value, date of purchase, brand name, etc.). No data on financial assets or debts is collected.

Russia: Rosstat, official statistical agency of Russia, implemented in 2003 a multi-topic survey, the Sample Survey of Household Welfare and Participation in Social 
Programmes, or NOBUS10 (for its Russian acronym). The sample is about 45,000 households, representative for 46 out of the 89 regions of the Russian Federation. The survey contains unusually (compared to HBS or RLMS, other household surveys available for Russia) detailed information on housing conditions and household durables. A key unique feature of the dataset (in Russia statistics) was a hypothetical question asking households to estimate rent payable to privately rent their dwelling unit. In combination with detailed data on housing characteristics it gives an opportunity to correctly estimate the implicit (imputed) rent.

Serbia: LSMS (Living Standards Measurement Survey) was conducted by a private research agency SMMRI under the contract with the social welfare ministry to compensate for the shortcomings of the official HBS. The survey was designed to be representative for six macro regions and within each region for urban and rural areas. The sampling procedure relied on a two-stage sampling. In total, 618 primary sampling units (enumeration districts) were selected for the sample. The survey was conducted twice, in 2002 and 2003 (on a sample of 2,500 households). The questionnaire design was based on the principle of combining critical elements of the LSMS model questionnaire (focus on the multi-dimensional aspects of living standards, focus on consumption measurement) with elements of the standard HBS (with expanded set of data on durables and productive assets). The survey has been accompanied by a unique (in the region) real estate survey implemented by Dragisa Bjeloglav (SMMRI).

\subsection{Valuing housing as an asset and as an element of current consumption}

To assess what actually happened to household wealth with housing privatization one needs more accurate estimates of estimates of the housing values. As in many Latin American countries (as shown by Torche and Spilerman 2006), in ECA there is no data collected on the value of housing possessed by households, and to derive exact parameters of housing wealth distribution one needs special set of assumptions, introduced below.

Opportunity cost approach relies on the observation that housing value and the flow of services from housing are two sides of the same coin. If we have one of them, we can estimate the other. Purchase of a housing unit with common financial terms of housing finance (down payment, years of mortgage, real interest rate, closure cost) is an estimated cost of homeownership. That monthly cost (plus maintenance) is an indication of the rent that should be charged for the owner unit to recover the investment.

Often neither of the two sides (market housing price and market rent) can be observed for the same unit. For imputing such missing values three methods are used: self-

10 Data, documentation and a selection of papers based on the NOBUS data are available on line at http://nobus.worldbank.org.ru. 
assessment, user costs, and extrapolation through hedonic regressions or stratification (Eurostat 2005). Among those, the user cost method can be applied only to derive macroeconomic (SNA) estimates and cannot be used at the micro level. Stratification is the method most frequently used in EU countries for HBS data. It consists of dividing housing stock into strata (by location, quality, size, etc.) and in using actual average market values to impute values to all units in a stratum. Hedonic regressions are often combined with self-assessment and following Rosen (1974) regress a set of characteristics of housing quality on the observed market rents or housing values (with subsequent extrapolation to non-renters or non-evaluated units), or on reported subjective assessments of such values. In the latter case predicted values by the regression are used to remove the outliers and carry out consistency checks with actual real estate market data.

When the aim is to construct housing wealth estimates and no data are available in the survey or from external sources, imputing back from rental prices is often used. Empirical studies of the developed rental and housing markets consistently find a tight relationship between the rent and the market price for the housing unit (for an example of tight links between average rent and house prices in Germany's länder see Palacin and Shelburne 2005). Such a relationship depends on the prevailing interest rate (and mortgage finance terms), and expected changes in housing prices. Often 'home rent or buy cost calculators' are used to assess opportunity costs of owning a house and allow derivation of a relationship specific to each time period and country. In each country, given differences in the available data, the analysis had to rely on different procedures.

Poland: housing value was imputed based on a two-stage procedure which used actual market rents. At the first stage (log) current market rental charge (for market renters) was regressed on apartment quality measured with its amenities and access to various facilities, its space, type of building, location, etc. Location has been measured with the following variables: region (voivodship), place of residence (rural or urban, plus the size of the city), and rate of unemployment in the region (as a proxy of the general quality of the neighbourhood). While overall all signs were correct, the fit $\left(\mathrm{R}^{2}\right.$ is only 0.08$)$ is low (see Toplinska and Kuhl 2003). The model was then used to predict values for nonrenters (owners) and those with social rents. For each owner-occupied dwelling imputed rent has been estimated using regression parameters and characteristics of the dwellings. Owners' imputed rent was recalculated into the housing price for each household using the mortgage calculator (which was reduced to Housing Asset=Monthly Rent * 750166.67). The value thus obtained has been compared to data from real estate agencies to ascertain broad accuracy.

Russia: imputing housing values had to use a different information base than in Poland given a much smaller market rental segment. Market-based transactions were a minority in Russia in 2003-less than 5 per cent of the tenants rented their dwellings from other private agents (households or companies). Of these, only half have reported the monthly 
rent they pay; a third of households nationwide rented their dwellings from government or municipal authorities and were paying 'social rent', a controlled price set well below the private market price.

The procedure to estimate housing values started with the imputation of rents and had to rely on reported subjective (implicit) rent by owners. In the NOBUS survey, the households who own their dwellings are asked to estimate the rental value of their dwelling - the amount of money they would have to pay if they would have to rent such a dwelling from a third party. These implicit rents were in the same range as the private market range (see Tesliuc and Ovcharova 2007 for details), and substantially above the 'social rents' paid by the tenants of government or municipal housing. Tesliuc and Ovcharova used a hedonic rent regression in which rents reported by a subset of the population (market-based or implicit rents) were regressed on a set of housing characteristics (number of rooms and measures of dwelling quality such as type of roof, floors, construction material of walls, type of sanitation, etc.), as well as regional and area dummies. The model has a reasonable fit, explaining 66 per cent of the variation in rents. Moreover, the coefficients of the model have the expected sign. Next, the parameter estimates obtained from this model were used to predict rental values for all households, under the assumption that the rents 'estimated' by homeowners included a non-systematic error term that the model eliminated. The final step was identical to Poland and consisted of converting the flow of rents into at estimation of housing asset value.

Serbia is the only country where the housing wealth calculation is direct. Assessment of home prices was conducted as part of the household survey. Assessment of each housing value was based on the data which was provided by the real estate agencies and housing transactions in 19 regions of the country where the survey has been conducted in order to get an average market value by type of house/apartment (taking into account the space and other characteristics of the real estate, nine different types of dwellings). The method used mimics almost exactly stratification approach. Based on housing values and assumed deprecation rates and cost of capital, the imputed rent was computed as annual flow of services for owner-occupied dwellings. Interestingly enough, the estimated owner-occupied rent was similar in both its median and mean values and shape to actual rents paid by those renting their dwellings.

There are a number of issues related to these approaches. Underdeveloped housing markets typically constrain the use of survey-generated data. Households may not be aware of the actual housing values of their dwellings or market rents. However, when such comparisons are made self-reported data are found to be accurate (Bucks and Pence 2005). There are also issues of self-selection when estimates from renters are used to impute values for owners. With the credit boom and increases in mortgage finances across the region, the assumption about zero debt made implicitly in all these calculations will soon become invalid and will require collection of household level data 
on net worth (or data on debt). Finally the questionnaires help to identify (with more or less precision) whether the respondent resides in a housing unit that was privatized, but given the time elapsed since privatization started and does not capture movers who purchased their properties by selling a privatized unit. But given very low residential mobility rates (less than 2 per cent in Russia; World Bank 2005a and 2005b), this introduces only a minimal bias.

\section{Outcomes of housing privatization in three countries: results for Poland, Russia, and Serbia}

To better understand the effects of privatization on the distribution of wealth and inequality we need to turn to survey data. Table 1 provides a basic introduction to the scale of privatization as picked up by household surveys and basic features of housing stock. To trace the effects of privatization, households which reside in privatized dwellings are identified and measured separately.

First, one can observe that the scale of housing privatization differed somewhat across countries, but everywhere it affected a sizeable subset of households. At this level of physical characteristics of housing stock one finds little inequality between homeowners and those who have privatized their dwellings. If anything, the 'privatizers' seem to enjoy less physical space than other households. Housing ownership rates (measured as percentage of population residing in housing units which belong to them) differ across countries, from over 90 per cent in Serbia to slightly over 60 per cent in Russia. Privatization seems to be sizeable, but far less than universal. Even in Russia where almost a third of the population directly benefited from privatization, the privatized housing represent only about a half of all housing stock.

Table 1: Poland, Russia, and Serbia: indicators of housing space for private owners, dwellers in privatized units and the entire population

\begin{tabular}{|c|c|c|c|c|c|c|}
\hline & \multicolumn{2}{|c|}{ Poland, 2001} & \multicolumn{2}{|c|}{ Russia, 2003} & \multicolumn{2}{|c|}{ Serbia, 2003} \\
\hline & $\begin{array}{c}\text { All } \\
\text { households }\end{array}$ & $\begin{array}{c}\text { Living in } \\
\text { privatized } \mathrm{H}\end{array}$ & $\begin{array}{c}\text { All } \\
\text { households }\end{array}$ & $\begin{array}{c}\text { Living in } \\
\text { privatized } \mathrm{H}\end{array}$ & $\begin{array}{c}\text { All } \\
\text { households }\end{array}$ & $\begin{array}{c}\text { Living in } \\
\text { privatized } \mathrm{H}\end{array}$ \\
\hline $\begin{array}{l}\text { Population } \\
\text { share, } \%\end{array}$ & 100.00 & 18.70 & 100.00 & 29.73 & 100.00 & 17.84 \\
\hline $\begin{array}{l}\text { Homeowners } \\
\text { to all, } \%\end{array}$ & 78.37 & 100.00 & 61.49 & 100.00 & 90.80 & 100.00 \\
\hline $\begin{array}{l}\text { Average } \\
\text { housing } \\
\text { space, } \mathrm{m}^{2}\end{array}$ & 69.7 & 53.3 & 36.8 & 32.9 & 73.1 & 70.3 \\
\hline $\begin{array}{l}\text { Gini index for } \\
\text { average space }\end{array}$ & 0.257 & 0.140 & 0.224 & 0.188 & 0.259 & 0.231 \\
\hline
\end{tabular}

Note: $\mathrm{H}=$ housing units, all data are population weighted.

Sources: Serbia, own estimates based on LSMS 2003; Russia, own estimates using NOBUS; Poland, own estimates based on HBS 2001 data. 
Ownership conditions reported by the respondents are also quite informative. Only in Poland are mortgages reported by a sizeable fraction of households ( 4 per cent), and mortgage use rates are not statistically different from zero in Russia and Serbia. This is confirmed by the banking statistics on outstanding mortgages to households reported by Palacin and Shelburne - in Poland at the end of 2001 they amounted to only 1.8 per cent of GDP; in Russia the earliest data for 2004 show only 0.4 per cent of GDP. Serbia by 2003 had no sizeable lending to households for housing finance. This information allows one to focus directly on housing value without worrying too much about liabilities while estimating household wealth in transition economies.

Table 2 presents one step further. Using results of housing assets valuation described in the previous section, it looks at their distribution among homeowners. Focusing first on basic descriptive statistics we see that the average price of housing is similar in Serbia and Poland (around €25,000) and was much less in Russia in 2003 (around €9,000). These values are estimates (except for Serbia where they come from real estate valuations) but seem to be in line with what is reported by real estate agents in Poland and Russia. Palacin and Shelburne report average prices of around $\$ 370 / \mathrm{m}^{2}$ in Poland (2001), and $\$ 455 / \mathrm{m}^{2}$ in Russia (2003). Multiplying by the average size of the unit and exchange rate the values are similar to the estimates reported in Table 2 (for Russia 2003: $\$ 455^{*} 35 \mathrm{~m}^{2} / 1.15 \$ / € \sim € 13,000$ ); Poland 2001: $\left.\$ 370 * 60 \mathrm{~m}^{2} / 0.9 \$ / € \sim € 24,000\right)$. This broad matching is important to validate the indirect estimate for these two countries. The estimate for Serbia is three times higher than the national account figure for imputed rents which relies on user cost method, highlighting the weaknesses of national accounting practices adopted in transition economies (Kovac and Radisavljevic 2006).

The distribution of housing wealth is interesting (and reported for the first time according to my knowledge). There is a sizeable inequality in housing values between the top (households holding the most valuable 20 per cent of housing stock) and bottom quintiles: 10 times difference in Russia, 12 times in Serbia and 3.5 times in Poland. Serbia appears as the country with highest housing wealth inequality according to the Gini index. Note that in Serbia housing values used are closer than anywhere else to actual market valuations of properties and thus are accurate. In Poland inequality is the lowest but also the assignment of housing values to households is the least accurate. 
Table 2: Poland, Russia, and Serbia: housing wealth for homeowners and \% privatized, by quintiles of housing wealth

\begin{tabular}{|c|c|c|c|c|c|c|c|c|c|}
\hline & \multicolumn{3}{|c|}{ Poland, 2001} & \multicolumn{3}{|c|}{ Russia, 2003} & \multicolumn{3}{|c|}{ Serbia, 2003} \\
\hline $\begin{array}{l}\text { Housing wealth } \\
\text { quintile }\end{array}$ & $\begin{array}{c}\text { Housing } \\
\text { value, } \\
\text { average } €\end{array}$ & $\%$ privatized & $\begin{array}{l}€ \mathrm{HV} \text { for } \\
\text { privatized }\end{array}$ & $\begin{array}{c}\text { Housing } \\
\text { value, } \\
\text { average } €\end{array}$ & $\%$ privatized & $\begin{array}{l}€ \mathrm{HV} \text { for } \\
\text { privatized }\end{array}$ & $\begin{array}{c}\text { Housing } \\
\text { value, } \\
\text { average } €\end{array}$ & $\%$ privatized & $\begin{array}{l}€ \mathrm{HV} \text { for } \\
\text { privatized }\end{array}$ \\
\hline $1^{\text {st }}$ (lowest) & 13,394 & 29.6 & 13,989 & 1,884 & 1.0 & 2,082 & 5,305 & 0.0 & 0 \\
\hline $2^{\text {nd }}$ & 18,920 & 38.7 & 18,989 & 3,696 & 5.1 & 4,244 & 9,936 & 2.9 & 12,604 \\
\hline $3^{r d}$ & 23,106 & 36.3 & 23,045 & 7,171 & 65.2 & 7,446 & 18,477 & 14.9 & 19,676 \\
\hline $4^{\text {th }}$ & 28,405 & 26.2 & 28,120 & 12,379 & 86.9 & 12,467 & 31,165 & 30.3 & 32,517 \\
\hline $5^{\text {th }}$ (highest) & 44,397 & 8.0 & 37,890 & 19,484 & 92.5 & 19,378 & 62,770 & 54.3 & 59,557 \\
\hline Average, $€$ & 25,644 & 27.8 & 21,800 & 8,921 & 50.1 & 13,503 & 25,507 & 20.5 & 44,423 \\
\hline Gini, HV & 0.239 & & 0.162 & 0.410 & & 0.227 & 0.454 & & 0.265 \\
\hline Gini, HW* & 0.402 & & 0.162 & 0.631 & & 0.227 & 0.504 & & 0.265 \\
\hline
\end{tabular}

Notes: weighted by households, non-owners excluded from calculations, average exchange rate for the surveys period used; in all countries except Serbia housing wealth is estimated based on imputed rent, procedure is described in Section 5 . HV = housing values for owner-occupied units. HW is housing wealth for all households, including zero for all non-owners. *Calculation includes zero value for non-homeowners

Sources: Serbia, own estimates based on LSMS 2003. Russia, own estimates using NOBUS 2003 based on imputed rent data by Tesliuc and Ovcharova (2007). Poland, own estimates based on HBS 2001 data with rents imputed by Topinska and Kuhl (2005). 
Inequality in housing values for Russia and Serbia (Gini $\sim 0.4$ ) seems similar to what is measured in OECD (for the USA, UK, and Israel, as reported by Sierminska and Garner 2002), and in line with the less unequal Latin American countries ( 0.60 for Chile, 0.56 for Uruguay, but 0.70 for Mexico and 0.85 for Bolivia-see Torche and Spilerman 2006). Poland stands out as having lowest inequality in housing wealth overall and between homeowners. This again is in line with the data from real estate agencies. As reported by Palacin and Shelburne (2005) in Russia prices per square meter ranged more widely: US\$2,000 for Moscow city centre versus US\$160 for Magadan. In Poland the variation was $€ 1,600 / \mathrm{m}^{2}$ for Warsaw city centre versus $€ 260 / \mathrm{m}^{2}$ in a secondary city.

Turning to the incidence of privatization across housing wealth distribution, one finds striking differences across countries. In Poland privatized stock is more or less evenly spread across the spectrum of lower and middle values. In Russia and Serbia low-value properties are virtually absent from the privatization (or more correctly put, prices of housing unit which fell into private hands outside privatization are below those of privatized units), and instead middle and especially top-value properties are overrepresented. Was it a self-selection, or simply privatization affected mostly areas which benefited from housing boom, occurring after (not necessarily due to) privatization? In Moscow, for example, housing prices increased by more than 40 per cent from $1999\left(\$ 700 / \mathrm{m}^{2}\right)$ to $2002\left(\$ 1000 / \mathrm{m}^{2}\right)$, and continued to climb further (to $\$ 3,000$ at the time of writing). Both factors interplay and with the data at hand it is impossible to differentiate between the two.

The data presented in Table 2 allow a simple experiment about the effect of housing privatization of wealth inequality. One might think that removing (higher value) privatized stock form the housing wealth distribution in Russia and Serbia, we will see less inequality among homeowners. But how much lower? Assume that there is no privatization, but all housing values remain the same (which is hardly realistic, but illustrative), for Russia then the Gini among homeowners would fall only marginally from 0.41 to 0.39 (but the average value of housing unit will be halved). For Serbia there would be a rather counter-intuitive increase from 0.454 to 0.461 (reducing by a quarter the price of an average housing unit). And also for Poland there would be an increase from 0.239 to 0.253 (with an increase in the average price).

Thus, despite clear over-representation of more valuable properties among privatizers in Russia and Serbia and under-representation in Poland, the effects of privatization on measured wealth inequality are not self-evident and require further investigation. To see even clearer the effects of privatization on equity, one can decompose inequality in housing wealth in accounting sense into the contribution of inequality 'between' groups and inequality 'within' groups using the Theil entropy measure of inequality (Bourguignon 1979; Shorrocks 1980). Let the population be divided into $m$ mutually exclusive and exhaustive subgroups. Let the population share of the $j^{\text {th }}$ group in the 
population be given by $w_{j}$, and the consumption share by $v_{j}$. For the Theil entropy measure $E(1)$ the decomposition is:

$$
E(1)=\sum_{j=1}^{m} v_{j} E(1)_{j}+\sum_{j=1}^{m} w_{j}\left[\frac{v_{j}}{w_{j}} \ln \left(\frac{v_{j}}{w_{j}}\right)\right],
$$

where $E(1)_{j}$ is the Theil entropy measure calculated for all individuals in subgroup $j$. The first summation is a weighted average (using consumption shares as weights) of the entropy measures calculated for the subgroups. Hence, this first term gives the component of overall inequality that is due to inequality within subgroups. The second summation is the entropy measure calculated on mean consumption of each subgroup (and weighting each subgroup by its population share). Hence, this second term gives the component of inequality that is due to between group differences. Table 3 reports results.

Table 3: Inequality in housing wealth and decomposition: non-privatized versus dwellers residing in privatized units

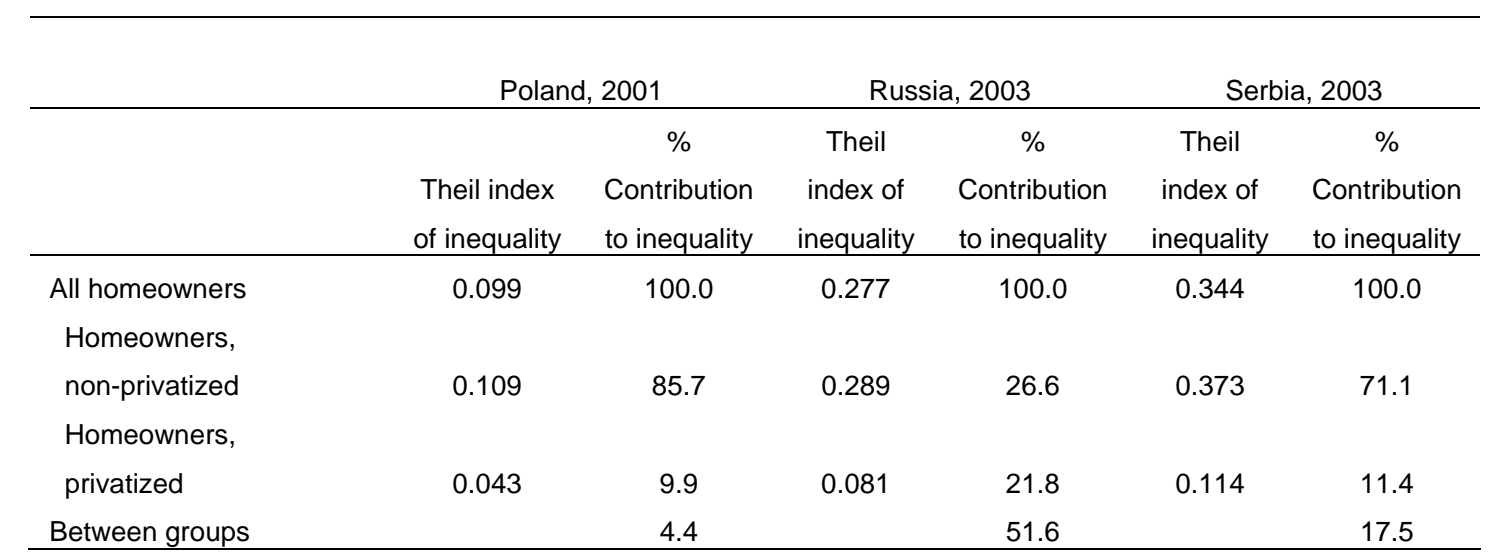

Notes: weighted by households; non-owners excluded from calculations

Sources: see Table 2.

The significance of data presented on Table 3 is that each country in the study has its unique configuration of inequality decomposition. In Serbia, the country with highest inequality in housing wealth, privatization added about one-quarter to (already high) inequality. In Russia, differences in values between privatized units and other properties combined with the significant scale of privatization made it the largest contributing factor of housing wealth inequality. In Poland limited scope of privatization, its promiddle class and pro-poor distributional pattern, and the relatively small size of privatization, resulted in minimum impact. The inequality in the distribution of housing asset in transition economies varies between these three countries depending on two factors: the size of the privatized stock and the policies that countries put in place to promote homeownership. 
Table 4: Consumption per capita, housing assets, share of homeowners and 'privatizers' by quintiles of consumption

\begin{tabular}{|c|c|c|c|c|c|c|}
\hline Consumption quintiles & CPC, monthly $€^{\star}$ & Housing wealth", $€$ & $\%$ homeowners ${ }^{\star \star \star}$ & House value for owners, $€$ & $\%$ privatizers ${ }^{\star \star \star}$ & $\begin{array}{l}\text { House value for } \\
\text { privatizers, } €\end{array}$ \\
\hline \multicolumn{7}{|l|}{ Poland } \\
\hline $1^{\text {st }}$ (poorest) & 60 & 18,339 & 72.4 & 25,320 & 8.2 & 21,296 \\
\hline $2^{\text {nd }}$ & 91 & 20,766 & 77.6 & 26,757 & 12.5 & 21,807 \\
\hline $3^{\text {rd }}$ & 120 & 22,117 & 79.9 & 27,666 & 17.8 & 22,544 \\
\hline $4^{\text {th }}$ & 157 & 21,981 & 80.1 & 27,456 & 23.3 & 22,460 \\
\hline $5^{\text {th }}$ (richest) & 258 & 23,373 & 81.8 & 28,565 & 32.0 & 23,458 \\
\hline Average, $€$ & 137 & 21,315 & 78.4 & 27,197 & 18.8 & 22,627 \\
\hline Gini, CPC & 0.307 & & & & & \\
\hline \multicolumn{7}{|l|}{ Russia } \\
\hline $1^{\text {st }}$ (poorest) & 25 & 3,882 & 55.7 & 6,973 & 18.6 & 13,916 \\
\hline $2^{\text {nd }}$ & 43 & 4,874 & 61.2 & 7,970 & 25.9 & 13,240 \\
\hline $3^{\text {rd }}$ & 58 & 5,500 & 62.3 & 8,829 & 30.4 & 13,332 \\
\hline $4^{\text {th }}$ & 76 & 6,310 & 63.1 & 10,001 & 33.3 & 14,205 \\
\hline $5^{\text {th }}$ (richest) & 125 & 7,281 & 65.2 & 11,158 & 40.5 & 14,275 \\
\hline Average, $€$ & 65 & 5,569 & 61.5 & 9,057 & 29.7 & 13,841 \\
\hline Gini, CPC & 0.304 & & & & & \\
\hline
\end{tabular}




\begin{tabular}{|c|c|c|c|c|c|c|}
\hline Serbia & & & & & & \\
\hline $1^{\text {st }}$ (poorest) & 55 & 16,307 & 91.0 & 17,918 & 9.7 & 43,198 \\
\hline $2^{\text {nd }}$ & 85 & 21,872 & 90.6 & 24,139 & 14.3 & 45,523 \\
\hline $3^{\text {rd }}$ & 112 & 23,946 & 91.2 & 26,247 & 17.8 & 49,077 \\
\hline $4^{\text {th }}$ & 146 & 27,582 & 91.5 & 30,134 & 23.0 & 46,218 \\
\hline $5^{\text {th }}$ (richest) & 241 & 30,516 & 89.7 & 34,039 & 24.5 & 46,557 \\
\hline Average, $€$ & 128 & 24,042 & 90.8 & 26,476 & 17.8 & 46,440 \\
\hline Gini, CPC & 0.290 & & & & & \\
\hline
\end{tabular}

Notes: *excluding rental costs for renters and imputed rent for owners. ${ }^{*}$ zeros for renters, population weighted. CPC = consumption per capita. ${ }^{\star * \star}$ population weighted Sources: see Table 2. 
Table 4 moves to the more interesting question of where the privatizers came from: the poor, middle, or rich classes. Linking housing wealth to the distribution of consumption (cleaned from rental costs and purchases of durables) Table 4 also puts data on homeownership in the spectrum of income distribution. All figures in Table 4 are population weighted and thus may differ from averages in Table 2.

First, relative ranking of countries according to inequality in current consumption fits expectations. In Russia top to bottom quintile ratio is $5: 1$, in Poland it is $4: 1$ and in Serbia 4.5:1. Second, share of homeowners varies by quintiles with expected correlations between homeownership and level of wellbeing (with a notable exception of Serbia, where it is homogeneous across all quintiles). But even the poorest have homeownership rates which are not dramatically different from the averages - a situation in deep contrast to OECD countries but similar to the one reported in Latin America (Torche and Spilerman 2006). Third, privatization universally, in all three countries favoured the rich (or households favoured by the privatization fared as better off). Particularly in Poland, despite its overall equitable pattern of distribution of privatized housing wealth, this result is interesting. It also suggests that unusually high ownership rates for the poor in transition economies studied here have nothing to do with specifics of their privatization programmes.

In full accordance with the evidence found in Latin America, the three countries studied here exhibit large variations of housing stock values across deciles even with homogeneous ownership rates. But this variation of housing wealth (or in the value of housing assets for owners) across quintiles of consumption is significantly less pronounced than the inequality in consumption itself or inequality in distribution of housing values (Table 2). Data presented in Tables 2 and 4 show that across the three countries there is less inequality in housing wealth among beneficiaries of privatization than among all homeowners. Thus, in sum, privatization transferred a relatively homogeneous stock to a sizeable fraction of households most of which turned out to be on top of the distribution. It therefore contributed to the increase of inequality. Thus, housing ownership was made more unequal by privatization, especially in the case of Russia. The resulting affects on overall inequality require change in the approach. Instead of treating separately housing assets and current consumption this requires combining them into one comprehensive measure of welfare. Indeed, ownership of housing generates service flows which form a part of current consumption levels. There is therefore a direct link through imputed rents.

Imputing rents also helps to put privatization into a broader context of housing ownership forms. As mentioned before, households residing in 'socially provided' housing continue to enjoy significant security of tenure and have in fact user rights that should be properly accounted for. So far in the analysis they were treated as non-owners with zero housing wealth. If one takes into consideration their imputed rent one can see whether (more unequal) housing ownership affected the inequality in living standards. 
To assess the effect of housing ownership on the overall levels of inequality it is important to integrate other durable assets in the analysis. All consumption expenditures on durable items are excluded from the consumption aggregate. Instead rental value of consumer durables is used. It is estimated by the cost of owning a durable good, which consists of two parts:

(i) depreciation: the drop in value of the good during the course of the year;

(ii) (forgone) real interest: the interest one could have earned if one had invested the money in a financial asset instead of a consumer good or the interest one has to pay on a loan taken out to finance the consumer good.

The exact procedure differed across countries. In Serbia again the extensive set of information collected by the LSMS allowed very precise estimates of service flows from durables. In Poland, it was based on rather arbitrary assumptions and relied only on ownership data. Russia falls in between.

Bringing together imputed and actual rents, flow of services from durables and consumption one can compensate for missing data on the value of physical assets in the available surveys and examine the joint distribution of wealth and current consumption. Following Shorrocks (1982) the contribution of each component $k$ is presented as the product of its concentration coefficient and share in total consumption; $G_{k}^{*}$, the concentration coefficient for component $k$ is:

$$
G_{k}^{*}=\frac{2}{\mu n^{2}} \sum_{i=1}^{n}\left(r_{i}-\frac{n+1}{2}\right) y_{k, i}
$$

where $y_{k, i}$ is component $k$ of the consumption of household $i$, mean total consumption is denoted by $\mu$, and $r_{i}$ is household's $i$ rank in the ranking of total consumption. It is different then from component 'own Gini' which shows the inequality in its own distribution (using its ranking). The overall Gini index is a weighted sum of the concentration coefficients:

$$
G=\sum_{k=1}^{K} \frac{\mu_{k}}{\mu} G_{k}^{*}=\sum_{k=1}^{K} S_{k} G_{k}^{*}
$$

Table 5 presents results for three countries and for three components of consumption: housing (rents imputed and actual), flow of services from durables, and the rest of consumption. 
Table 5: Decomposition results for inequality in consumption

\begin{tabular}{|c|c|c|c|c|c|}
\hline Components of consumption & $\begin{array}{c}\text { Average monthly } \\
\text { value, } €\end{array}$ & Structure \% & Own inequality, Gini & $\begin{array}{c}\text { Concentration } \\
\text { coefficient }\end{array}$ & $\begin{array}{c}\text { Contribution to } \\
\text { inequality }\end{array}$ \\
\hline \multicolumn{6}{|l|}{ Poland } \\
\hline $\begin{array}{l}\text { All consumption per capita } \\
\text { of which }\end{array}$ & 151.91 & 100 & 0.291 & 1.000 & 100 \\
\hline Imputed and act rents per capita & 10.49 & 7 & 0.317 & 0.204 & 5 \\
\hline Imputed flow form durables per capita & 9.00 & 6 & 0.422 & 0.312 & 6 \\
\hline All other components of consumption & 132.42 & 87 & 0.297 & 0.296 & 89 \\
\hline \multicolumn{6}{|l|}{ Russia } \\
\hline All consumption per capita & 83.52 & 100 & 0.282 & 1.000 & 100 \\
\hline \multicolumn{6}{|l|}{ Of which } \\
\hline Imputed and act rents per capita & 16.21 & 19 & 0.449 & 0.264 & 18 \\
\hline Imputed flow form durables per capita & 1.96 & 2 & 0.526 & 0.288 & 2 \\
\hline All other components of consumption & 65.36 & 78 & 0.304 & 0.286 & 79 \\
\hline \multicolumn{6}{|l|}{ Serbia } \\
\hline All consumption per capita & 165.43 & 100 & 0.292 & 1.000 & 100 \\
\hline \multicolumn{6}{|l|}{ Of which } \\
\hline Imputed and act rents per capita & 34.56 & 21 & 0.498 & 0.359 & 26 \\
\hline Imputed flow form durables per capita & 3.23 & 2 & 0.635 & 0.396 & 3 \\
\hline All other components of consumption & 127.64 & 77 & 0.290 & 0.271 & 72 \\
\hline
\end{tabular}

Source: See Table 2. 
Data presented in Table 5 show clearly that the distribution of housing assets has a significant impact on consumption levels. Poland looks like an outlier with housing rents or flow of services accounting for only 7 per cent of consumption, but since these figures are related to plausible estimates of housing values they should not be too out of line. In Serbia and Russia (excluding all utilities) accounts for 20 per cent of total consumption. Household ownership of durables plays a less significant role as a factor of current consumption levels and hence represent a weaker driver of inequality.

Ginis for housing rent show that the underlying distribution of ownership and use rights is more unequal than the apparent distribution of consumption. This is in particular the case for Serbia (Gini for rent 0.498) and Russia. But generally even concentration of housing values across consumption deciles makes it a weak contributing factor of inequality. Concentration coefficients for imputed rents in Poland and Russia fall below the overall Gini, only in Serbia is it noticeably above (0.359 versus 0.292 ).

Thus housing in fact produces overall equalizing effect on distribution in Serbia and Russia, but the size of this effect is small. In Poland, the Gini moves from before rent to after rent with imputations from 0.297 to 0.291 ; in Russia from 0.304 to 0.282. In Serbia the effect is slightly disequalizing, the Gini moves with inclusion of rents from 0.290 to 0.292. Note that it is Serbia where privatization had the weakest effect on the distribution of housing, only exacerbating pre-existing inequalities. Nowhere the size of effect is near the scale measured by Buckley and Gurenko (1997) for 1993 (due to imputations for user rights and own housing the Gini consumption dropped from 0.41 to 0.35 in Russia).

\section{Discussion and implications}

Based on the analysis presented in the previous section, the role of housing privatization as a driver of inequality if wealth and in consumption has become clearer. While scale and even the direction of effects from housing privatization differs across countries studied in this paper, nowhere does it form a major factor. Given its overall disequalizing effect on the distribution of housing wealth privatization weakened the 'progressive' (in distributional accounting sense) impact of the legacy of uniform housing on inequality. As a result the overall distribution in early 2002 was less distorted by the factor of (non-market) housing allocation than it was in the early 1990s as reported by Buckley and Gurenko (1997) and Milanovic (1990). But it was not a major pro-poor force, as it is sometimes portrayed. Even more, given a relatively short time span the distribution of housing wealth in favour of the better off induced by privatization in some countries (in our study, Serbia and Russia), the regressive effects are not negligible.

One can speculate that by moving high-value housing to the market privatization contributed perhaps to developing market depth and thus to greater liquidity of housing 
and spendability of this asset. It therefore could have had positive effects on the wealth of the poorly endowed as well. But since no causation can be established, it is sufficient to note that privatization definitely affected wellbeing of a large group of people in a similar way but its effects on the wealth inequality differed dramatically across countries and privatization strategies pursued.

The results obtained through the analysis of housing values in micro datasets can help to gauge the parameters of the overall distribution of wealth in transition economies. Very little is known about the structure of wealth holdings. The accounting methods based on 'book values' produce figures which fail to account for inflation or changes in economic valuation of assets. Lack of micro data seriously hampers the study of wealth distribution. The scale of privatization can be more accurately measured based on estimates in this paper.

Poland transferred the least ownership through privatization: only 16 per cent of total national housing stock value. But it represents as much as $€ 53$ billion in 2001 prices. Using information from the World Bank World Indicators analyzed in Davies and Shorrocks (2005), one can estimate overall wealth holdings in the following simple way:

— financial assets $=€ 77.8$ billion

— liabilities $=€ 18.1$ billion

— housing assets $*=€ 335.9$ billion

— durables* $=€ 11.2$ billion

*estimated in this paper.

Russia privatized 44 per cent of its housing stock by value. Tenants who privatized their dwellings now constitute about half of all homeowners. Housing privatization had a large effect on wealth holding. Estimates of housing wealth presented in this paper contribute to the study of household balance sheets using also data from Rosstat (2003):

\section{housing, all stock}

housing, in private hands

of which privatized

durables

financial assets

HH term deposits

saving deposits

cash holdings (inc. hard currency)

actual final consumption of $\mathrm{HH}$

GDP
$€ 574.36$ billion*

$€ 315.64$ billion*

$€ 234.84$ billion*

$€ 107.82$ billion

$€ 29.90$ billion

$€ 52.39$ billion

$€ 12.14$ billion

$€ 220.79$ billion

$€ 379.58$ billion 
Memo:
housing stock (official balance value)
$€ 199.59$ billion
all productive assets(official balance value) $€ 539.12$ billion
incomes from property (SNA)
$€ 19.84$ billion

Serbia has the least developed data on wealth among the three countries studied, but using unusually detailed LSMS data one can compensate for the shortcomings of official statistics and get some idea of their relative importance in the household balance sheet for 2003:

$\begin{array}{ll}\text { housing } & € 65.775 \text { billion* } \\ \text { of which privatized } & € 20.216 \text { billion* } \\ \text { all agric. HH assets (including land) } & € 9.691 \text { billion* } \\ \text { durables } & € 4.427 \text { billion* }\end{array}$

financial assets

banking deposits $\quad € 1.768$ billion

liabilities $€ 0.564$ billion

These simple estimates show that in the countries studied housing remains predominant for household assets. This paper has looked at the role and distribution of housing stock as an economic asset in a transition economy, and at its effects on the distribution of current consumption. In all three countries we find that inequality in the value of housing was much lower among those who privatized their dwellings than broadly among homeowners. Those who have privatized their homes seem to enjoy higher levels of consumption. Features of the privatization programmes have not favoured the poor in particular, but were based on a rather egalitarian distribution among the beneficiaries. As a result the inequality in the distribution of housing asset in transition economies varies between these countries depending on two factors: the size of the privatized stock and the policies that countries put in place to promote homeownership. Poland seems to be achieving the best outcomes in terms of housing inequality even though its privatization programme is much smaller than that of Russia. This shows the importance of broad housing market reforms to achieve better access to housing.

Some observed irregularities suggest that Russia in particular needs to implement its housing reform to address some of the emerging issues. Despite its seemingly egalitarian legacy the country appears to have one of the most unequally distributed housing stock and have low-value housing. The recently adopted housing code ended the open-ended right to privatize. In Serbia with its deeply unequal distribution of housing the problem seems to lie elsewhere - an insufficient supply of better quality housing due to a poor financial framework and legal problems in setting up an efficient housing market. Practically missing rental housing stock is a sign of these problems. 
The result is that a majority of the housing stock in Serbia is not managed and maintained as though it were privately owned.

Despite a common belief and some earlier evidence the paper does not find significant effects of housing on consumption inequality. When owner-occupied housing rents and durables are properly accounted for, the effects of housing is mildly progressive in Russia and Poland and regressive in Serbia, but the contribution of housing to the inequality is not more than 1-2 percentage points of Gini. This is due primarily to the emerging closer relationship between the welfare of households, their current consumption, and the quality and quantity of housing. This represent a change compared to the situation observed in early transition when connections between household wealth and current consumption was weak.

The paper identifies a number of gaps in the data. First, in no survey are respondents asked to provide a market valuation of their dwelling. Second, a proper understanding of housing market and mobility is impossible without collecting data on the history of dwelling purchase/rental. Finally the estimate of the housing net worth requires collection of data on mortgages and housing debts, but currently such information is not systematically collected. Housing finance for individual units is now rapidly developing in a number of transition countries and interest rate margins are falling rapidly, particularly in those countries where banks have linked with foreign investors who have played a significant role in bank restructuring. Better data are needed to manage risks associated with this process and equality implications require serious policy discussions.

Overall the information collected through existing household surveys used in this study seems to provide enough data to make a first rough measurement of housing wealth distribution, but further progress depends on addressing the gaps. This will help to provide more accurate estimates of increasingly important factor of wellbeing in transition countries.

\section{References}

Alexeev, M., and C. Gaddy (1993). 'Income Distribution in the USSR in the 1980s', Review of Income and Wealth 39: 23-36.

Aron, J., J. Muellbauer, and J. Prinsloo (2006). 'Estimating the Balance Sheet of the Personal Sector in an Emerging Market Country', paper presented at the UNUWIDER project meeting on Personal Assets from a Global Perspective, 4-6 May, Helsinki.

Bertaud, A., and B. Renaud (1997) 'Socialist Cities without Land Markets', Journal of Urban Economics 41(1) 137-51.

Bourguignon, F. (1979). 'Decomposable Income Inequality Measures', Econometrica 47(4): 901-20. 
Buckley, R., and E. Gurenko (1997). 'Housing and Income Distribution in Russia: Zhivago's Legacy', World Bank Research Observer 12(1): 19-32.

Bucks, B., and K. Pence (2005). 'Measuring Housing Wealth', paper prepared for the LWS conference on Construction and Usage of Comparable Microdata on Wealth, 27-29 January, Perugia.

Commander, S., A. Tolstopiatenko, and R. Yemtsov (1999). 'Channels of Redistribution: Inequality and Poverty in the Russian Transition', Economics of Transition 7(2): 411-47.

Davies, J., and A. Shorrocks (2005). 'Wealth Holdings in Developing and Transition Countries', paper prepared for the LWS conference on Construction and Usage of Comparable Microdata on Wealth, 27-29 January, Perugia.

Dübel, H.-J., W.J. Brzeski, and E. Hamilton (2005). Rental Choice and Housing Policy Realignment in Transition: Post-privatization Challenges in the Europe and Central Asia Region, World Bank: Washington DC.

Eurostat (2005). 'HBS and EU-SILC Imputed Rent', paper prepared for the First Meeting of the Working Group on Living Conditions, 8-10 June, Luxembourg.

Flemming, J., and J. Micklewright (1999). 'Income Distribution, Economic Systems and Transition', in A.B. Atkinson and F. Bourguignon (eds) Handbook of Income Distribution, Elsevier Science: Amsterdam.

Guzanova, A. (1998). 'The Housing Market in the Russian Federation: Privatization and its Implications for Market Development', World Bank Policy Research Department Working Paper 1891, World Bank: Washington DC.

Jäntti M., and E. Sierminska (2006). 'Wealth Distribution in OECD Countries: Evidence on the Level and Distribution across Selected Countries', paper prepared for the UNU-WIDER project meeting on Personal Assets from a Global Perspective, 4-6 May, Helsinki.

Kovac, I., and G. Radisavljevic (2006). 'Estimating Rentals of Dwelling Services by the User Cost Approach in Serbia', paper presented at Eurostat-OECD Workshop on the Non-Observed Economy for the Western Balkan Region, 23-25 January, Paris.

Li, S., and R. Zhao (2006) 'The Changes in Distribution of Wealth in China, 19922002', paper prepared for the UNU-WIDER project meeting on Personal Assets from a Global Perspective, 4-6 May, Helsinki.

Macours, K., and J.F.M. Swinnen (2005). 'Agricultural Labor Adjustments in Transition Countries: The Role of Migration and Impact on Poverty', Review of Agricultural Economics 27(3): 405-11. 
Markham, M. (2003). 'Poland: Housing Challenge in a Time of Transition', paper prepared for the project HUT-264M Housing Policy in the United States: The Intersection of Public and Private Sectors in Housing Finance, Washington DC

Milanovic, B. (1990). 'Poverty in Poland, Hungary and Yugoslavia in the Years of Crisis, 1978-87', World Development Report Working Paper 507, World Bank: Washington DC.

Mitra, P., and R. Yemtsov (2006). 'Increasing Inequality in Transition Economies: Is There More to Come?', paper presented at the Annual Bank Conference on Development Economics Beyond Transition, 18-19 January, St Petersburg.

Muellbauer, J. (2006). 'Housing and Personal Wealth in a Global Context', paper prepared for the UNU-WIDER project meeting on Personal Assets from a Global Perspective, 4-6 May, Helsinki.

Palacin, J., and R. Shelburne (2005). 'The Private Housing Markets in Eastern Europe and in the CIS', United Nations Economic Commission For Europe Economic Analysis Division Discussion Paper 6, UNECE: Geneva.

Rosen, S. (1974). 'Hedonic Prices and Implicit Markets: Product Differentiation in Pure Competition', Journal of Political Economy 82(1): 34-55.

Rosstat (various). Russian Statistical Yearbook, Rosstat: Moscow.

Rozelle, S., and J.F.M. Swinnen (2004). 'Success and Failure of Reform: Insights from the Transition of Agriculture', Journal of Economic Literature 42: 404-56.

Shorrocks, A. (1980). 'The Class of Additively Decomposable Inequality Measures', Econometrica 48(3): 613-25.

Shorrocks, A. (1982). 'Inequality Decomposition by Factor Components', Econometrica 50(1): 193-211.

Sierminska, E., and T. Garner (2002). 'A Comparison of Income, Expenditures and Home Market Value Distributions Using Luxembourg Income Study Data from the 1990s', Maxwell School of Citizenship and Public Affairs Working Paper 338, Syracuse University: Syracuse NY.

Struyk, R.J. (1996). Economic Restructuring of the Former Soviet Bloc: The Case of Housing, Urban Institute Press: Washington DC.

Subramanian, S., and D. Jayaraj (2006). 'The Distribution of Household Wealth in India', WIDER Research Paper 2006/116, UNU-WIDER: Helsinki.

Tesliuc, E., and L. Ovcharova (2007). Sensitivity of Poverty and Inequality Statistics to Alternative Definitions of Household Welfare Illustration Using the NOBUS Survey, World Bank: Washington DC. 
Topińska, I., and K. Kuhl (2003). 'Poverty in Poland: Profile and Changes, 1994-2001', in Poland: How Far Is Warsaw From Lisbon? Growth, Employment and Living Standards in Pre-Accession Poland, World Bank: Washington DC.

Torche, F., and S. Spilerman (2006). 'Household Wealth in Latin America', paper prepared for the UNU-WIDER project meeting on Personal Assets from a Global Perspective, 4-6 May, Helsinki.

UNECE (United Nations Economic Commission for Europe) (various). Country Profiles on the Housing Sector, UNECE: Geneva.

World Bank (2001). Urban Housing and Land Market Reforms in Transition Countries: Neither Marx Nor Market, World Bank: Washington DC.

World Bank (2005a). Growth, Poverty and Inequality in Eastern Europe and Former Soviet Union, World Bank: Washington DC.

World Bank (2005b). Russian Federation: Reducing Poverty through Growth and Social Policy Reform, Poverty Reduction and Economic Management Unit, Europe and Central Asia Region, World Bank: Washington DC.

Zavisca, J. (2005). 'Housing Divides: The Causes and Consequences of Housing Inequality in Russia' (mimeo), Center for Russian, East European, and Eurasian Studies, University of Texas at Austin: Austin TX. 